\title{
ANALISIS KEPUASAN PASIEN DAN KARYAWAN DENGAN METODE HUMAN SIGMA STUDI KASUS DI PT RSI MABARROT MWC BUNGAH KABUPATEN GRESIK
}

\author{
Suparno (1), Roikhan (2), Nurul Hamidah (3) \\ 1,2,3 Program Studi Teknik Industri, Sekolah Tinggi Teknik Qomaruddin Gresik \\ Jalan Raya No. 01 Bungah Gresik 61152
}

\section{ABSTRAK}

1suparnostta@gmail.com

Kepuasan pasien dan karyawan terhadap rumah sakit salah satu faktor yang penting karena dapat membentuk loyalitas karyawan terhadap rumah sakit dengan memberikan pelayanan terbaik untuk pasien yang akhirnya akan dapat membentuk loyalitas pasien terhadap rumah sakit itu sendiri. RSI Mabarrot MWC NU Bungah Gresik merupakan salah satu rumah sakit swasta yang selalu mengutamakan kepuasan pasien dan karyawan yang professional dalam memberikan pelayanan terbaik kepada pasien, yang mana pada periode januari sampai desember 2016 tingkat kepuasan pasien masih belum stabil. Penelitian ini bertujuan untuk mengukur kepuasan karyawan dan pasien dengan human sigma serta perencanaan strategi dengan analisis SWOT. Berdasarkan analisis yang dilakukan, dapat diketahui bahwa nilai human sigma rumah sakit sebesar $34.89 \%$, yang berada pada kuadran 2 dan human sigma 3. Artinya, RSI Mabarrot MWC NU Bungah memiliki kinerja keuangan yang dikatakan menengah atau rata-rata dan hanya salah satu dari subjek (dalam hal ini adalah pasien) yang hubungannya terhadap rumah sakit bernilai optimal (partial optimized). Selain itu, diperoleh nilai kepuasan perawat dan pasien yang sudah cukup tinggi yang ditunjukkan dengan nilai employee engagement (EE) sebesar 51,7\% dan nilai customer engagement (CE) sebesar $47,1 \%$. Berdasarkan hasil penelitian didapat rancangan strategi menggunakan IFE, EFE dan SWOT bagi rumah sakit guna meningkatkan nilai Human Sigma yang nantinya akan meningkatkan kinerja keuangan rumah sakit.

Kata kunci: Rumah Sakit, Human Sigma, Employee engagement, customer engagement, IFE, EFE, SWOT

\section{PENDAHULUAN}

Seiring dengan semakin tingginya tingkat pendidikan, ilmu pengetahuan, pesatnya teknologi kedokteran serta kondisi sosial ekonomi masyarakat, kesadaran tentang pentingnya kesehatan dalam masyarakat meningkat pula. Hal ini mengakibatkan kebutuhan dan tuntutan masyarakat terhadap pelayanan kesehatan yang berkualitas semakin tinggi pula. Salah satu industri atau instansi yang bergerak dalam bidang jasa adalah rumah sakit.

Kualitas pelayanan adalah hal yang penting untuk diperhatikan, karena hal tersebut akan dipersiapkan oleh konsumen mengkonsumsi barang atau jasa. Hubungan antara pasien, karyawan dan rumah sakit akan membentuk adanya ikatan emosional. Ikatan emosional yang baik antara karyawan dan rumah sakit akan mengakibatkan kenyamanan karyawan dalam melakukan pekerjaanya yang kemudian akan membentuk loyalitas karyawan terhadap rumah sakit dengan memberikan pelayanan terbaik untuk pasien. Sehingga akan berpengaruh terhadap ikatan emosional antara karyawan dengan pasien, dalam memberikan pelayanan yang baik secara langsung terhadap pasien juga akan dapat membentuk loyalitas pasien terhadap rumah sakit itu sendiri. Dengan demikian kepuasan pasien dan karyawan terhadap rumah sakit menjadi salah satu faktor yang penting karena dapat memberikan keuntungan kepada rumah sakit. 
Metode yang dapat digunakan untuk mengukur kepuasan pelanggan dalam hal ini pasien dan mengukur kepuasan karyawan yaitu metode Human Sigma. Metode Human Sigma adalah sebuah metode untuk mengukur kepuasan pelanggan yang dikembangkan oleh John H. Fleming, Curt Coffman dan James Harter. Didalam metode human sigma hubungan antara karyawan dengan pelanggan menjadi hal yang sangat penting karena ikatan emosional antara keduanya dapat memberikan keuntungan bagi perusahaan (Fleming, 2007). Dengan metode Human Sigma dapat diketahui nilai Human Sigma (HS), keeratan hubungan pelanggan terhadap karyawan (CE) dan keeratan hubungan pelanggan (EE), sebagai bahan evaluasi kinerja pelayanan rumah sakit dan dapat dijadikan dasar pemikiran strategi rumah sakit. Kualitas pelayanan menjadi suatu keharusan yang harus dilakukan perusahaan supaya mampu bertahan dan tetap mendapat kepercayaan pelanggan. Pola konsumsi dan gaya hidup pelanggan menuntut perusahaan mampu memberikan pelayanan yang berkualitas. Dari pengertian diatas dapat disimpulkan kepuasan konsumen adalah tanggapan konsumen mengenai kesesuaian atau ketidaksesuaian tingkat harapan konsumen dengan kenyataan yang dirasakan setelah membeli produk atau jasa.

Metode Human Sigma pertama kali diperkenalkan John $\mathrm{H}$. Fleming, C. Coffman dan James K. Harter pada 2005 sebagai sebuah model dan pendekatan disertai aturan-aturan baru untuk menilai mutu interaksi karyawan dan para pelanggan serta aspek pengelolaan dan perbaikan hubungan keduanya. Beberapa prinsip pokok penggunaan metode Human Sigma seperti dalam penilaian terhadap interaksi antara karyawan dan pelanggan yang sangat berbeda dengan penilaian terhadap produk manufaktur. Human Sigma bicara tentang emosi dan perilaku manusia namun sifatnya tidak universal. Hubungan karyawan dengan pelanggan perlu dipelihara sedemikian rupa karena ada pengaruhnya terhadap kinerja finansial. Kesehatan hubungan karyawan dan pelanggan jangka panjang menjadi sangat penting, karena itu perlu didekati secara holistik. Pendekatan mutu sumber daya manusia (SDM) di setiap kelompok yang terkait dengan strategi bisnis dalam bentuk pelatihan terpadu, riview kinerja, kegiatan pembelajaran terprogram, dan bimbingan individual menjadi sangat strategis untuk dilakukan perusahaan (Fleming, 2007).

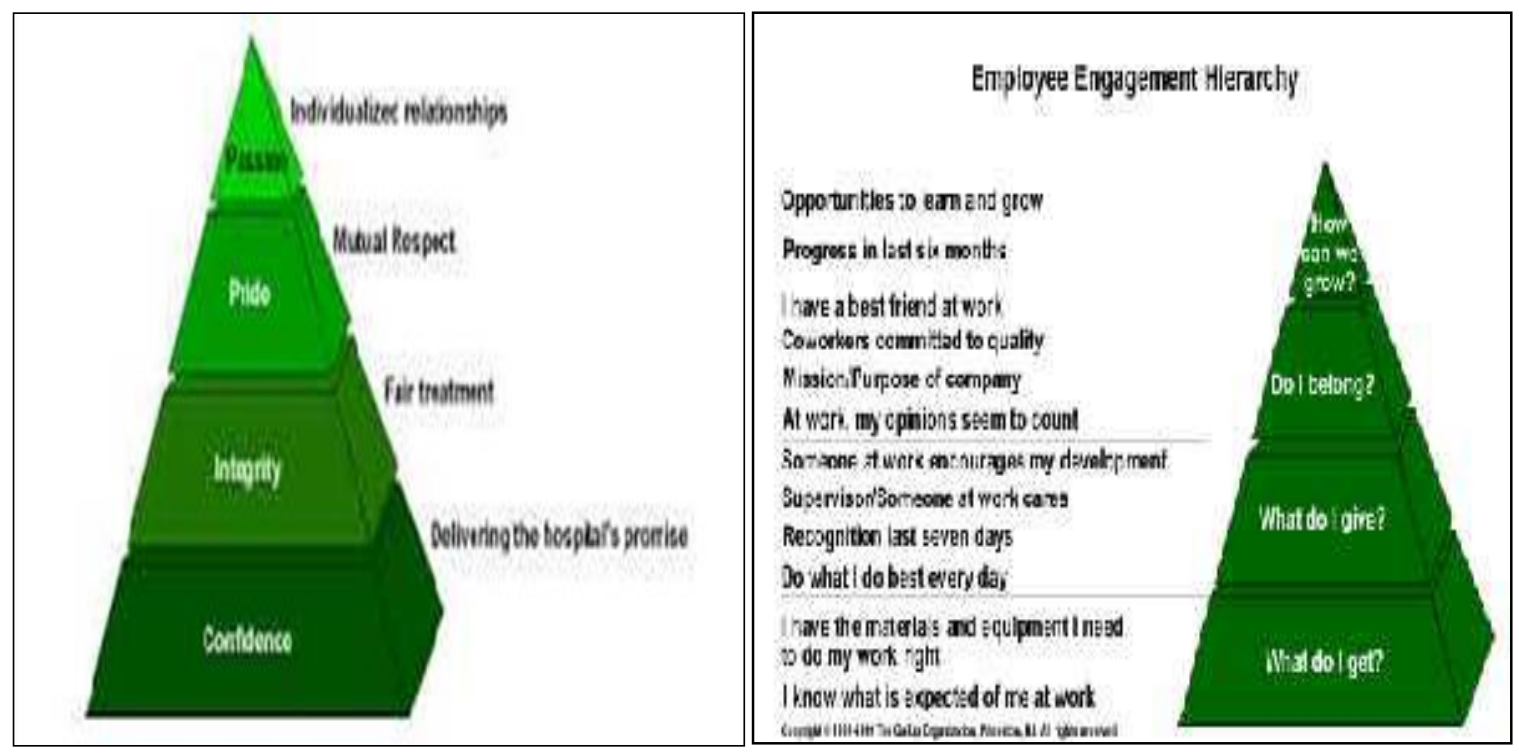

Gambar 1. Piramida 4 Dimensi Ikatan Emosional (Fleming, 2007) 
Fleming (2007) membagi pelanggan menjadi 4 jenis berdasarkan tingkat ikatan emosionalnya terhadap perusahaan, yaitu: a. Fully Engaged : Pelanggan yang memiliki ikatan emosional yang kuat dengan perusahaan dan amat loyal terhadap perusahaan.

b. Engaged: Pelanggan belum seutuhnya terbentuk ikatan dengan perusahaan namun telah terbentuk fondasi untuk membentuk ikatan yang lebih kuat.

c. Not Engaged : Pelanggan ini secara emosional dan perilaku cenderung netral, tidak memiliki ikatan emosional apapun dengan perusahaan manapun.

d. Actively Disengaged : Pelanggan ini adalah pelanggan yang memiliki perasaan yang negatif terhadap perusahaan. Selain itu mereka juga dapat memberikan pengaruh buruk terhadap pelanggan.

\section{Tingkatan-tingkatan Mutu Interaksi dalam Human Sigma}

Sistem pengukuran human sigma dengan pengukuran kuantitatif dengan menggunakan 4 jenjang dimensi ikatan emosional (Gambar 1) yaitu :

1. Confidence (kepercayaan pelanggan terhadap perusahaan)

2. Integrity (tingkat konsistensi pelanggan dalam menggunakan produk jasa perusahaan

3. Pride (tingkat kebanggan pelanggan terhadap produk atau jasa suatu perusahaan, atau terhadap perusahaan itu sendiri).

4. Passion (tingkat ketergantungan pelanggan terhadap produk / jasa).

\section{Employee Engagement}

Level individu menunjukkan bagaimana perusahaan berinteraksi dengan pelanggan mereka secara personal.

a. What Do I Get : Dimensi ini biasa disebut sebagai basic need. Kebutuhan dasar atau basic need merupakan landasan utama dari pembentukan ikatan emosional pegawai dengan perusahaan.

b. What Do I Give : Dimensi ini menunjukkan besar kontribusi karyawan kepada perusahaan (individual contribution). c. Do I Belong : Dimensi yang menunjukkan pada faktor lingkungan kerja atau faktor eksternal selain karyawan itu sendiri, seperti rekan kerja, atasan, sahabat, serta visi dan misi perusahaan.

d. How Can We Grow : Dimensi ini lebih mengarah pada peran dari perusahaan terhadap kemajuan karyawannya. Peran serta perusahaan inilah yang akan membantu proses pembentukan dimensi ini demi tercapainya employee engagement.

\section{Parameter Employee Engagement}

Untuk pengukuran hubungan karyawan digunakan survey pertanyaan berjenjang dengan urutan sebagai berikut (Fleming, 2007):

a. Saya tahu apa yang diharapkan dari saya tentang pekerjaan ini.

b. Saya memiliki segala sesuatunya untuk melakukan pekerjaan ini dengan benar.

c. Dalam bekerja, saya memiliki kesempatan untuk melakukan yang terbaik setiap harinya

d. Dalam tujuh hari terakhir, saya mendapat pujian atas hasil kerja saya.

e. Atasan saya terlihat sangat memperhatikan saya sebagai bawahan.

f. Atasan dan teman-teman saya selalu mendorong saya untuk senantiasa lebih maju lagi

g. Pendapat saya selalu diperhatikan oleh atasan dan teman saya.

h. Tujuan perusahaan ini sudah jelas dan membuat saya merasa dibutuhkan dalam pekerjaan ini.

i. Teman-teman saya memiliki komitmen yang kuat untuk memberikan yang terbaik untuk perusahaan.

j. Saya memiliki teman-teman terbaik dalam pekerjaan.

k. Dalam enam bulan terakhir ini seseorang telah menyatakan bahwa saya memiliki kemajuan yang positif dalam pekerjaan.

1. Dalam setahun belakangan ini, saya memiliki kesempatan untuk belajar dan berkembang. 


\section{Parameter Costumer Engagement}

Untuk melakukan pengukuran hubungan pelanggan digunakan survey pertanyaan berjenjang dengan urutan sebagai berikut (Fleming, 2007):

a. Secara keseluruhan, apakah anda puas terhadap produk.

b. Apakah anda akan senantiasa menggunakan produk ini.

c. Apakah anda merekomendasikan produk ini kepada orang lain?

d. Produk ini adalah produk yang dapat dipercaya.

e. Produk ini adalah yang sesuai dengan yang dijanjikan.

f. Perusahaan ini selalu mengutamakan kepuasan pelanggan.

g. Produk ini selalu menjadi solusi kebutuhan saya.

h. Saya merasa bangga memakai produk ini.

i. Perusahaan ini selalu memperhatikan kebutuhan pelanggan.

j. Produk ini adalah produk yang sempurna untuk saya.

k. Saya tidak dapat membayangkan bila didunia ini tidak ada produk ini.

\section{METODE PENELITIAN}

Metode yang digunakan dalam penelitian ini adalah metode deskriptif kuantitatif. Dimana penelitian diarahkan untuk mengurai atau menjelaskan secara rinci ekspetasi pelanggan dengan kenyataan pelayanan yang diperoleh dengan menggunakan kuesioner yang bersifat tertutup.

Teknik pengumpulan data primer dan data sekunder, perlu dibuat kuesioner yang perlu diuji kevalidannya. Salah satu cara untuk menguji validitas sebuah data yang didapat menggunakan kuesioner, adalah dengan menggunakan SPSS dan menggunakan fungsi correlations. Jika nilai probabilitas total rata-rata untuk tiap nomor adalah kurang dari 0,05 sig (2-tailed) < dari alfa) maka pertanyaan pada nomor tersebut dapat dikatakan valid. Demikian juga kuesioner perlu diuji reliabilitasnya untuk mengukur bahwa kuesioner dapat dipercaya dan diandalkan dalam penguuran berulang kali tetap konsisten. Metode yang digunakan dalam menentukan tingkat reabilitas adalah angka cronchbach, jika nilainya lebih besar dari 0,06 maka hasil data dari kuesioner tersebut dapat dikatakan memiliki tingkatan reliabilitas yang baik. Perhitungan jumlah sampel $\mathrm{n}$ untuk penyebaran kuesioner ditentukan dari rumus slovin sebagai berikut :

$$
\mathrm{n}=\frac{N}{1+N e^{2}}
$$

Keterangan

$\mathrm{n}=$ ukuran sampel

$\mathrm{N}=$ ukuran populasi

$\mathrm{e}=$ nilai kritis

Hasil perhitungan didapatkan sampel kuesioner perawat adalah 30 dan didapat kuesioner pasien 52 . Untuk setiap pertanyaan diberikan skala likert 1 hingga satuan nilai tertinggi misalnya 5 mulai dari sangat tidak setuju, tidak setuju, netral, setuju dan sangat setuju.

\section{Pengujian Uji Validitas dan Realibiltas Kuesioner Pasien}

Uji validitas untuk pelanggan atribut 1 didapat nilai korelasi sebesar dengan probabilitas korelasi [sig.(2-tailled)] sebesar 0.000 sehingga bisa dikatakan valid, karena memiliki nilai korelasi [sig.(2tailed) < dari taraf signifakan $(\alpha)$ sebesar 0.05 . Begitu pula untuk instrument atau pertanyaan kuesioner yang lain. Hal ini menunjukkan bahwa setiap nomor pada kuesioner tersebut adalah valid. Sedangkan uji reliabilitas untuk pasien. Melalui perhitungan software SPSS diatas, nilai alpha croncbach adalah 0,754. Lebih besar 0.7 artinya atribut-atribut kuesioner yang diberikan kepada pelanggan sudah reliable.

\section{Uji Validitas Kuesioner dan Realibiltas Perawat}

Dari atribut 1 diperoleh probalilitas korelasi [sig.(2-tailed)] sebesar 0.000 . sesuai criteria sebelumnya, instrument kuesioner atribut 1 adalah valid karena memiliki nilai korelasi [sig.(2-tailed) < dari taraf signifakan $(\alpha)$ sebesar 0.05 . Begitu pula untuk instrument atau pertanyaan kuesioner yang lain. Hal ini menunjukkan bahwa setiap nomor pada kuesioner tersebut adalah valid. Sedangkan uji reliabilitas nilai alpha croncbach adalah 
0,767 dimana $>0,7$ berarti alat tes kuesioner dengan atribut-atribut sudah reliable.

\section{Metode Analisis Data}

Pengukuran Human Sigma menggunakan 2 pengukuran kuantitatif sebagai input, yaitu : Nilai kuantitatif hubungan karyawan-perusahaan atau Employee Engagement (EE) dan hubungan pelanggan-perusahaan atau Customer Engagement (CE)

Human Sigma $=$

$(\text { EE Persentil x CE Persentil) })^{0,5} \mathrm{x}$

(Persentil maks./Persentil ./

Persentil min $)^{0,5}$

Rumus diatas adalah untuk kasus diman EE Persentil dan CE Persentil adalah diatas median distribusi. Sedangkan bila salah satu ada yang kurang dari median distribusinya datanya maka Human Sigma $=((\text { EE Persentil } x \text { CE Persentil }) / 2)^{0,5}$

\section{HASIL DAN PEMBAHASAN}

Nilai Customer Engagement pasien dihitung dengan mengurutkan nilai dari setiap pelanggan dari yang terkecil sampai terbesar diperoleh:

- CE Persentil $=24,5 / 52=0,471$ atau $47,1 \%$
- $\quad$ Median $=3.812$

- $\quad$ Mean = 3,802 (< median)

- CE Index $=($ mean/5) $\times 6=(3,802$

15) $\times 6=4.562$

Dapat dilihat bahwa rata-rata dari 52 data yang didapatkan adalah 3,802. Untuk menghitung nilai Employee Engagement pasien adalah dengan mengurutkan nilai dari setiap pasien dari yang terkecil sampai yang terbesar :

- $\quad$ EE Persentil $=14.5 / 28=0,517$ atau

- $\quad$ Median = 3,687

$$
51.7 \%
$$

- $\quad$ Mean = 3,625 $(<$ median $)$

- $\quad$ EE Index $=($ mean/5) x $6=3,665 / 5)$ $\times 6=4,398$

Dapat dihitung bahwa rata-rata dari 30 data yang didapatkan adalah 3.625. Karena nilai CE lebih kecil dari 50\%, maka perhitungan nilai HS-nya adalah sebagai berikut :

HS persentil=

((EE persentil rumah sakit $\quad 0,5$

$\mathrm{x}$ CE persentil rumah sakit)/2)

$=((0,517 \times 0.471) / 2)^{0,5}=0,3489=$ $34.89 \%$

EE persentil adalah $51,7 \%$ dan CE persentil $47,1 \%$, maka kuadran HS -nya berada pada kuadran 1 dan HS 3. Kondisi adalah partially optimized atau optimal sebagian karena salah satu nilai yaitu nilai CE tidak optimal. Nilai Human Sigma tersebut berhubungan dengan kekuatan keuangan secara keseluruhan pada unit.

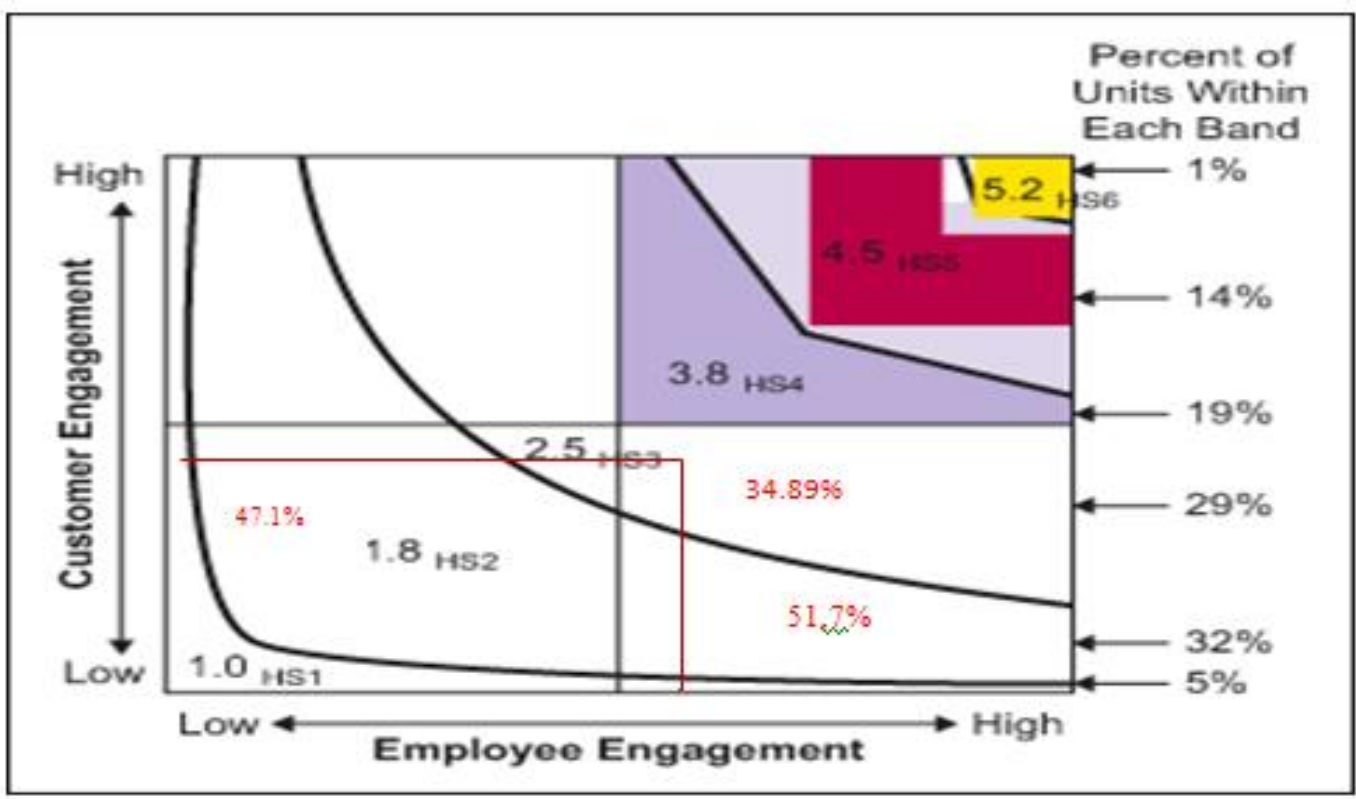

Gambar 2. . Kuadran Human Sigma 


\begin{abstract}
Dapat dilihat bahwa melalui perhitungan didapatkan nilai angka sebesar $33.69 \%$. Angka tersebut memiliki artian bahwa unit dari pelayanan tersebut telah memberikan kontribusi yang baik untuk posisi keuangan. Sedangkan kualitas hubungan antara perusahaan dan karyawan relatif cukup baik karena lebih dari $50 \%$. Sedangkan kualitas hubungan antara pasien dan rumah sakit masih kurang sehingga perbaikannya adalah menjadi sangant penting untuk perbaiakan kinerja perusahaan. Maka perbaikan akan lebih fokus pada peningkatan hubungan antar pasien dan rumah sakit tersebut.
\end{abstract}

\section{Analisis Dimensi Ikatan Emosional Karyawan}

Untuk memperoleh suatu ikatan emosional antara perawat dan perusahaan terdapat 4 dimensi yang dijadikan sebagai acuan yaitu:

1. What Do / Get

Karyawan dituntut paham terhadap tanggung jawab tugasnya dan perusahaan wajib memenuhi fasilitas untuk tercapainya tugas karyawan.

2. What Do I Give

Dimensi individual contribution yang menunjukkan tingkat kotribusi setiap karyawan kepada perusahaan, pelanggan, atasan, rekan-rekan kerja.

3. Do I Belong

Menciptakan kerja sama diantara karyawan yang baik dan harus bisa menghilangkan ego pribadi dan mementingkan diri sendiri.

4. How Can We Grow

Pengembangan diri karyawan harus ditabnamkan dalam motivasi kerja sehingga dalam menjalankan tugasnya dilakukan dengan penuh tabggung jawab dan bisa bekerja dengan nyaman tidak merasa tertekan dan ada rasa iri pada rekan lain.

\section{Analisis Dimensi Ikatan Emosional Pasien}

Untuk memperoleh suatu ikatan emosional antara pasien dan rumah sakit terdapat 4 dimensi yang dijadikan sebagai acuan yaitu:

1. Confidence

Jenis pelayanan yang dianggap memenuhi janji atau sesuai kebutuhan adalah bahwa apa yang dijanjikan oleh pihak rumah sakit terhadap pasien tersebut memang sesuai dengan apa yang dibutuhkan oleh pasien

2. Integrity

Tingkat konsistensi pelanggan dalam menggunakan produk jasa perusahaan. Managemen tidak membedakan pelayanan terhadap semua pelanggan.

3. Pride

Manajemen membangun tingkat kebanggan pelanggan terhadap produk atau jasa suatu perusahaan, atau terhadap perusahaan itu sendiri.

4. Passion

Manajemen bisa menginformasikan pelanggan setia sehingga menimbulkan tingkat ketergantungan pelanggan terhadap produk / jasa)

\section{KESIMPULAN}

Perhitungan human sigma yang diperoleh RSI MWC MABARROT NU Bungah Gresik sebesar $34.89 \%$ yang berada pada kuadran 2 dan HS 3 artinya rumah sakit memiliki kinerja keuangan yang dikatakan menengah atau rata-rata. Nilai kepuasan perawat rumah sakit (EE) sudah cukup optimal yaitu sebesar $51,7 \%$, namun peluang perbaikannya masih sangat terbuka. Nilai kepuasan pasien rumah sakit belum optimal atau relatif cukup rendah yaitu $47,1 \%$, sehingga peningkatan nilai customer engagement (CE) menjadi sangat penting untuk perbaikan kinerja rumah sakit.

\section{DAFTAR PUSTAKA}

Fleming, J, H., Coffman \& J. K. Harter. 2005. Manage Your Human Sigma, Harvard Business Review. New york: The Gallup Organization.

Fleming, J, H. \& J. Asplund. 2007. Human Sigma. New York: Gallup Press.

Tjiptono, F. 2004. Pemasaran Jasa. Malang: Banyumedia.

Umar, Husein. 2010. Desain Penelitian MSDM dan Perilaku Karyawan: Paradigma Positivistik dan Berbasis Pemecahan Masalah. Jakarta: Rajawali Pers. 